\title{
Chemical Standards and HPTLC Finger Print Profiles of a Siddha Polyherbal Formulation - Kadukkai Legiyam
}

\author{
Research Article
}

\section{Sujith Thatipelli ${ }^{1}$, Achintya Kumar Mandal ${ }^{2}$, Shakila Ramachandran ${ }^{\text {* }}$}

\author{
1.Research Assistant (Chemistry), 2. Assistant Research Officer (Chemistry), \\ 3. Research Officer (Chemistry), Department of Chemistry,
}

Siddha Central Research Institute (Central Council for Research in Siddha, Ministry of AYUSH, Government of India), Anna Hospital Campus, Arumbakkam, Chennai, Tamil Nadu, India.

\begin{abstract}
To study physico-chemical, phytochemical and high performance thin layer chromatography of a Siddha drug "Kadukkai Legiyam" (KL). The prepared Kadukkai Legiyam (KL) was prepared as per the standard operating procedures mentioned in literature. Then the drug was subjected to physicochemical parameters, phytochemical screening, thin layer chromatographic photo documentation (TLC), high performance thin layer chromatographic (HPTLC) finger print profile of hexane, chloroform, ethanol and hydro alcohol (1:1) extracts. Different extracts of the drug showed distinct TLC and HPTLC finger print patterns which will be unique to this drug. This study giving information about physiochemical and phytochemical analysis and HPTLC fingerprint profile of different extracts, the integration spectrum which will useful in standardizing the raw drugs and future comparison studies.
\end{abstract}

Key Words: Siddha medicine, Kadukkai legiyam, Terminalia chebula, TLC, HPTLC.

\section{Introduction}

Siddha system of medicine is traditional and ancient medicinal system in India. There is growing importance in traditional health systems in providing healthcare for a wider population across the globe, especially in the developing countries. WHO currently encourages, recommends and promotes traditional as well as natural remedies in all over the world and national healthcare programs, as they are easily available at low cost, no side effects and traditionally acceptable. Traditional healing system around the world that utilizes herbal remedies is an important resource for the discovery of modern drugs. Siddha system has flourished well in South India. The traditional Indian Siddha medicine system supports the importance of medicinal plants to treat diseases.

Kadukkai Legiyam is a polyherbal formulation mentioned in Siddha system of medicine. It is prescribed for treating many illnesses, like anuria, constipation, veneral heat, burning sensation in palm, painful diseases, heat in the anal region, generalized oedema and tuberculosis. Five to ten grams twice daily is the dosage (1).

The purpose of this research is to give information about standardization of Kadukkai Legiyam through physicochemical, phytochemical analysis and high performance thin layer chromatograph (HPTLC). Physico chemical study such as loss on drying, ash values, extractive values, $\mathrm{pH}$, phytochemical analysis and HPTLC finger print

\section{* Corresponding Author:}

\section{Shakila Ramachandran}

Research Officer (Chemistry) Department of Chemistry, Siddha Central Research Institute (Central Council for Research in Siddha, Ministry of AYUSH, Government of India), Anna Hospital Campus, Arumbakkam, Chennai-600106, Tamil Nadu, India. India.

Email Id: rshakila@gov.in parameters had been developed for Kadukkai Legiyam in different extracts. It will be useful in standardizing the raw drugs as well as the herbal medicines.

Kadukkai mathirai, another traditional Siddha Medicine containing Terminalia chebula as major ingredient, is used for the treatment of liver diseases, prokinetic and iron deficiency anemia (2). It has been reported to exhibit hepato protective activity (3). Kadukkai is considered as safe as no adverse effect on biochemical and hematological parameters and histopathology of kidney, liver, and spleen was observed even after administering these drugs for a long period (4) and also exhibit hypo lipidemic activity also (5).

Terminalia chebula is the major ingredient of Kadukkai Legiyam. Constituents of T. chebula are gallic acid, chebupentol, terchebin, ellagitannin, terchebulin, arjunolic acid, arjungenin, terminoic acid ferulic acid, vanilic acid, $p$-coumaric acid, caffeic acid, fatty acids and tannin (6). It is used for the treatment of various diseases like diabetes, asthma, diarrhea, mouth ulcers, skin allergies, acidity, fever, constipation, to prevent hair loss, dandruff and used for weight loss. The plant possesses multiple pharmacological and medicinal activities, such as antioxidant, antimicrobial, antidiabetic, hepatoprotective, anti-inflammatory, antimutagenic, antiproliferative, cardioprotective, antiarthritic, anticaries, gastrointestinal motility, wound healing activity (7), antioxidant, radioprotector (8), antiarthritic (9) and disease modifying activity (10).

\section{Materials and Methods \\ Plant collection}

All the ingredients were purchased from local herbal suppliers and authenticated by the Research Officer (Pharmacognosy) of this Institute.

\section{Ingredients in Kadukkai Legiyam \\ Kadukkai Legiyam contains 20 different ingredients as listed in the Table 1.}




\section{Preparation of Kadukkai Legiyam}

Powdered the ingredients from Sl.no.1 to 17 separately and taken the drug as per the quantity mentioned in the table 1. Added ghee in to sugar and heated. To this, the powdered ingredients were added and stirred continuously till obtaining the consistency of legiyam. Removed from heat and allowed to cool. Added with honey and mixed well for homogeneity.

Table 1: Ingredients of Kadukkai Legiyam

\begin{tabular}{|c|c|c|c|c|}
\hline $\begin{array}{l}\text { S. } \\
\text { No. }\end{array}$ & Tamil Name & Botanical Name & Part Used & $\begin{array}{c}\text { Quan } \\
\text { tity } \\
\text { (in g) }\end{array}$ \\
\hline 1 & Kadukkai & $\begin{array}{c}\text { Terminalia chebula } \\
\text { Retz. }\end{array}$ & Fruit rind & 350 \\
\hline 2 & Civathai & $\begin{array}{l}\text { Operculina turpethum } \\
\text { (L.) Silva Manso }\end{array}$ & Root & 70 \\
\hline 3 & Karisalai & Eclipta prostrata L. & $\begin{array}{l}\text { Whole } \\
\text { plant }\end{array}$ & 70 \\
\hline 4 & Vallarai & $\begin{array}{c}\text { Centella asiatica }(\mathrm{L} .) \\
\text { Urban }\end{array}$ & $\begin{array}{l}\text { Whole } \\
\text { plant }\end{array}$ & 70 \\
\hline 5 & Puliyarai & Oxalis corniculata L. & Leaf & 70 \\
\hline 6 & Nila avarai & $\begin{array}{c}\text { Cassia angustifolia } \\
\text { Vahl. }\end{array}$ & Leaf & 70 \\
\hline 7 & Katukurohini & $\begin{array}{l}\text { Picrorrhiza kurroa } \\
\text { Royle ex Benth }\end{array}$ & $\begin{array}{l}\text { Root \& } \\
\text { Rhizome }\end{array}$ & 9 \\
\hline 8 & Kirampu & $\begin{array}{l}\text { Syzygium aromaticum } \\
\text { (L.) Merr. \& Perry }\end{array}$ & $\begin{array}{l}\text { Flower } \\
\text { bud }\end{array}$ & 9 \\
\hline 9 & Thippilli & Piper longum L. & Fruit & 9 \\
\hline 10 & Cirunakappu & $\begin{array}{l}\text { Cinnamomum wightii } \\
\text { Meissn. }\end{array}$ & $\begin{array}{l}\text { Flower } \\
\text { bud }\end{array}$ & 9 \\
\hline 11 & Valuluvai & $\begin{array}{l}\text { Celatrus paniculatus } \\
\text { Willd. }\end{array}$ & Seed & 9 \\
\hline 12 & Karkatasringi & $\begin{array}{l}\text { Pistacia integerrima } \\
\text { Stewart ex Brandis }\end{array}$ & Gall & 9 \\
\hline 13 & Karunjeeragam & Nigella sativa L. & Seed & 9 \\
\hline 14 & Milagu & Piper nigrum L. & Fruit & 9 \\
\hline 15 & Thandrikkai & Terminalia bellirica $\mathrm{L}$. & Fruit rind & 9 \\
\hline 16 & Kotamalli & Coriandrum sativum L. & Fruit & 9 \\
\hline 17 & Thalisapattiri & $\begin{array}{c}\text { Taxus baccata auct. } \\
\text { non L. }\end{array}$ & Leaf & 9 \\
\hline 18 & Sugar & Saccharum officinarum & - & 1550 \\
\hline 19 & Ney (Ghee) & Bos indicus & - & 800 \\
\hline 20 & Ten (Honey) & Apies mellifera & - & 400 \\
\hline
\end{tabular}

\section{Physicochemical parameters}

All the physiochemical parameters of KL were carried out as per standard methods (11).

\section{Phytochemical Screening}

All the Qualitative Phytochemical tests of KL were done by using the standard methods (12).

\section{Chemicals, solvents and materials}

Analytical grade solvents $n$-hexane, chloroform, toluene, ethyl acetate, ethanol and formic acid were purchased from Merck. For visualizing purpose vanillin (1 g) dissolved in sulphuric acid $(5 \mathrm{ml})$ in ethanol $(95 \mathrm{ml})$ (VSA) was used.

\section{Preparation of extracts for TLC/HPTLC}

The drug ( $2 \mathrm{~g})$ was packed in a thimble made up of Whatman filter paper and kept in a Soxhlet extractor. Extracted successively with $n$-hexane, chloroform, ethyl acetate and ethanol (each $50 \mathrm{ml}$ ). After extraction, filtered the extracts and concentrated in vacuo using rotary evaporator (Buchi Laboratory Technique Limited, Switzerland) at $40^{\circ} \mathrm{C}$ and finally made up to $10 \mathrm{ml}$ in standard flasks. In the case of hydro alcohol extract $5 \mathrm{~g}$ of sample were soaked for $24 \mathrm{~h}$ in $50 \%$ of alcohol $(50 \mathrm{ml}$ ethanol $50 \mathrm{ml}$ water $)$. At the end of extraction, each extract was passed through Whatman filter paper no. 1. The yellowish green filtrates obtained were concentrated in vacuo using rotary evaporator (Buchi Laboratory Technique Limited, Switzerland) at $40^{\circ} \mathrm{C}$. The final products were sticky dark-brown substances, which were redissolved in corresponding solvents and stored in sample vials and used for HPTLC fingerprint profile.

\section{Mobile Phases}

The mobile phases for $n$-hexane extract, hexane : ethyl acetate $(10: 1.6 \mathrm{v} / \mathrm{v})$; for chloroform, toluene : ethyl acetate : formic acid $(9: 1: 0.5, v / v / v)$; for ethanol, toluene : ethyl acetate : formic acid $(6: 2: 0.6, v / v / v)$; for hydro alcohol extract, toluene : ethyl acetate : methanol $(3: 4: 3, v / v / v)$.

\section{Instrument}

For HPTLC, aluminium plate precoated with Silica gel $60 \mathrm{~F}_{254}$ (Merck) of $0.2 \mathrm{~mm}$ thickness was used. Automatic sampler ATS4 for extract application on TLC plate, twin trough chamber $(10 \times 10 \mathrm{~cm})$ for plate development, visualizer for photo documentation under UV-visible conditions, Scanner 4 with winCATS software for finger prints, TLC plate heater for derivatization (all from CAMAG, Switzerland) were used.

\section{Procedure for TLC/HPTLC}

All the extracts $(5,10 \& 15 \mu l)$ were applied separately in 4 different TLC plates of size $6 \mathrm{~cm} \times 10 \mathrm{~cm}$ as 8 $\mathrm{mm}$ bands at a height of $10 \mathrm{~mm}$ from bottom, $15 \mathrm{~mm}$ in Xaxis. The TLC plates were developed in the respective mobile phases finalized. The developed plates were air dried, viewed under UV $254 \mathrm{~nm}$ and $366 \mathrm{~nm}$ and the images were documented followed by scanning under $\lambda 254 / 366$ wavelengths using deuterium lamp in absorption and $\mathrm{Hg}$ lamp in fluorescence mode. Then the plates were dipped in a dip tank containing VSA reagent and heated at $105^{\circ} \mathrm{C}$ till the appearance of colored spots. Immediately the derivatized TLC plates were photo documented and scanned at a wavelength of $520 \mathrm{~nm}$ using $\mathrm{W}$ lamp in absorption mode.

\section{Results and Discussions}

\section{Physico-chemical Studies}

All the physicochemical results of KL were carried out in duplicate and the mean values are presented in the Table 2. Since KL is a legiyam, the loss on drying was estimated as $14.29 \%$ which denotes the high moisture including volatile substances. The total ash was determined as $1.68 \%$ which shows that $98.32 \%$ of the drug is organic in nature and only $1.68 \%$ is inorganic in nature and in which $1.11 \%$ are water soluble in nature. More than half of the drug $(55.99 \%)$ is soluble in water and about one third of the drug $(35 \%)$ is soluble in alcohol. The drug is acidic in nature $(\mathrm{pH}$ $=4.39$ ) and the reducing sugar is $7.68 \%$ and total sugar $16.93 \%$. Pharmacopoeial standards are an essential requirement for any herbal drugs (13).

Table 2: Physico chemical values of $K L$

\begin{tabular}{|c|l|c|}
\hline Sl.No & \multicolumn{1}{|c|}{ Parameters } & $\begin{array}{c}\text { Mean } \\
\text { values }\end{array}$ \\
\hline 1 & Loss on drying at $105^{\circ} \mathrm{C}(\%, \mathrm{w} / \mathrm{w})$ & 14.29 \\
\hline 2 & Total Ash $(\%, \mathrm{w} / \mathrm{w})$ & 1.68 \\
\hline 3 & Water soluble ash $(\%, \mathrm{w} / \mathrm{w})$ & 1.11 \\
\hline 4 & Acid insoluble ash $(\%, \mathrm{w} / \mathrm{w})$ & 0.08 \\
\hline 5 & Water soluble extractive $(\%, \mathrm{w} / \mathrm{w})$ & 38.18 \\
\hline 6 & Alcohol soluble extractive $(\%, \mathrm{w} / \mathrm{w})$ & 26.25 \\
\hline 7 & $\mathrm{pH}(10 \%$ solution $)$ & 4.39 \\
\hline 8 & Reducing sugar $(\%, \mathrm{w} / \mathrm{w})$ & 7.68 \\
\hline 9 & Total sugar $(\%, \mathrm{w} / \mathrm{w})$ & 16.93 \\
\hline
\end{tabular}




\section{Phytochemical Screening}

The results of qualitative phytochemical test of KL are presented in the Table 3 . The phytochemical tests revealed that the drug is rich in all categories of phytochemicals because of which the drug may have wide variety of therapeutic uses.

Table 3: Phytochemicals of KL

\begin{tabular}{|c|l|c|}
\hline S.No & Phytochemical & Inference \\
\hline 1 & Phenol & + \\
\hline 2 & Tannin & + \\
\hline 3 & Flavonoids & + \\
\hline 4 & Triterpenoids & + \\
\hline 5 & Proteins & - \\
\hline 6 & Glycosides & + \\
\hline 7 & Reducing sugar & - \\
\hline 8 & Anthraquinones & + \\
\hline 9 & Quinones & + \\
\hline 10 & Alkaloids & + \\
\hline 11 & Saponins & + \\
\hline 12 & Cardiac glycoside & + \\
\hline 13 & Coumarin & + \\
\hline 14 & Acids & + \\
\hline
\end{tabular}

(Note: + indicates present and - indicates absent)

\section{Chromatographic studies}

The TLC of $n$-hexane extract of KL (Fig. 1) showed four spots at $R_{f} 0.05,0.09,0.20,0.28$, (all green) under $U V$ $254 \mathrm{~nm}$; twelve spots at $\mathrm{R}_{\mathrm{f}} 0.05$ (sky blue), 0.06 (light pink), 0.08 (sky blue), 0.13 (Brown), 0.16 (Pink), 0.23, 0.27 (all Red), 0.30 (Blue), 0.40 (Green), 0.67, 0.74, 0.82(all Blue), under UV $366 \mathrm{~nm}$; six spots at $\mathrm{R}_{\mathrm{f}} 0.22$ (Ash), 0.27 (Black), 0.30 (Light Yellow), 0.39 (Ash), 0.86 (Black) \& 0.91 (Light Yellow) under white light (after dipping in VSR).TLC profile of successive chloroform extract of KL (Fig. 1) showed four spots at $\mathrm{R}_{\mathrm{f}}$ 0.10, 0.13, 0.21, 0.26 (all green) under UV 254 $\mathrm{nm}$; twelve spots at $\mathrm{R}_{\mathrm{f}} 0.07,0.11$ (all Sky Blue), 0.13 (Light Green), 0.15 (Blue), 0.18 (Pink), 0.36, 0.40, 0.44, 0.48 (all Sky Blue), 0.55 (Ash), 0.61 (Blue), 0.74 (Blue) under UV $\lambda$ $366 \mathrm{~nm}$; six spots at $\mathrm{R}_{\mathrm{f}} 0.22,0.27,0.30,0.39,0.86,0.91$ (all are of ash color), under white light (after dipping in VSR).

TLC photo documentation of the successive ethanol extract of KL (Fig. 1) showed four spots at $R_{f} 0.14,0.40,0.54$ (all green) under UV $\lambda 254 \mathrm{~nm} ; 10$ spots at $R_{\mathrm{f}} 0.08$ (Blue), 0.18 (Sky Blue), 0.27 (Sky blue), 0.32 (Blue), 0.38 (Sky Blue), 0.50 (Light Green), 0.59, 0.71 (all Blue), 0.80 (Sky Blue), \& 0.92 (Blue) were seen under UV $\lambda 366 \mathrm{~nm}$; three spots with $\mathrm{R}_{\mathrm{f}} 0.13$ (Light Brown), 0.60 (Ash), \& 0.69 (Ash) were found under white light (after dipping in VSR). TLC profile of the hydro alcohol extract of KL (Fig. 1) shows six spots at $\mathrm{R}_{\mathrm{f}} 0.04,0.13,0.21,0.36,0.57,0.69$ (all green) were found under UV $\lambda 254 \mathrm{~nm}$; four spots at $\mathrm{R}_{\mathrm{f}} 0.04$ (Sky Blue), 0.14 (Blue), 0.36 (blue) \& 0.40 (Sky Blue) were seen under UV $\lambda 366 \mathrm{~nm}$; and five spots with $\mathrm{R}_{\mathrm{f}} 0.07$ (Black), 0.15 (Black), 0.25,0.36 (all Ash) \&0.43 (Light Pink) were found under white light (after dipping in VSR).

HPTLC profile of hexane extract (Fig. 2) under UV $254 \mathrm{~nm}$, major peaks $\left(4,12\right.$ and 13) appeared at $\mathrm{R}_{\mathrm{f}} 0.19$ (area $38.40 \%), 0.86(16.49 \%)$ and $0.89(14.25 \%)$; under $366 \mathrm{~nm}$, major peaks $(5,7,9$ and 10$)$ at $\mathrm{R}_{\mathrm{f}} 0.26$ (area 12.54\%), 0.39 (12.72\%), 0.67 (17.37\%) and $0.71(11.96 \%)$; HPTLC profile of chloroform extract (Fig. 3) under UV 254 nm, major peaks (6, 7 and 14) appeared at $\mathrm{R}_{\mathrm{f}} 0.20$ (area 39.60\%), 0.26 $(18.25 \%)$ and $0.95(13.76 \%)$; under $366 \mathrm{~nm}$, major peaks (4,
5 and 6) at $\mathrm{R}_{\mathrm{f}} 0.37$ (area 53.54\%), 0.40 (18.44\%) and 0.45 (16.86\%); HPTLC profile of ethanol extract (Fig. 4) under UV $254 \mathrm{~nm}$, major peaks (3, 7 and 8) appeared at $\mathrm{R}_{\mathrm{f}} 0.15$ (area 21.48\%), 0.42 (24.49\%) and 0.56 (33.48\%); under 366 $\mathrm{nm}$, major peaks $\left(2,4\right.$ and 13 ) at $\mathrm{R}_{\mathrm{f}} 0.21$ (area 10.90\%), 0.28 $(20.52 \%)$ and $0.82(14.24 \%)$; HPTLC profile of hydro alcohol extract (Fig. 5) under UV $254 \mathrm{~nm}$, major peaks (2, 3, 5 and 8) appeared at $\mathrm{R}_{\mathrm{f}} 0.13$ (area 13.87\%), 0.22 (18.11\%), $0.36(11.55 \%)$ and $0.69(20.31 \%)$ under $366 \mathrm{~nm}$, major peaks $\left(2,3,4\right.$ and 5) at $\mathrm{R}_{\mathrm{f}} 0.33$ (area 12.27\%), 0.38 (18.08\%), 0.41 (28.10\%) and 0.93 (34.37\%); after derivatization with VSR, at $520 \mathrm{~nm}$, showed major peaks $\left(2,3,5\right.$ and 6) at $\mathrm{R}_{\mathrm{f}} 0.12$ (29.43\%), 0.17 (25.24\%), 0.40 (10.38\%) and 0.43 (15.99\%).

Figure 1. TLC photo documentation of different extracts of $K L$

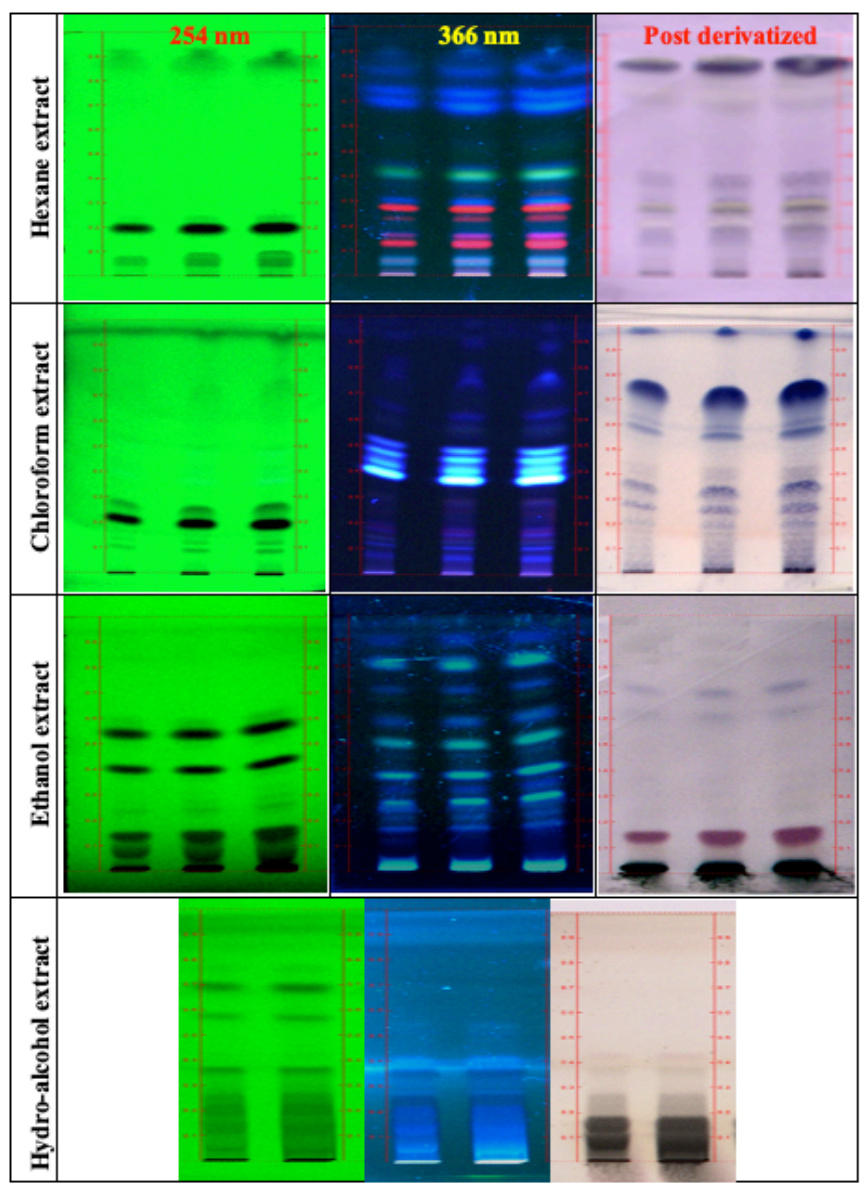

Figure 2. HPTLC finger print profile of hexane extract of KL

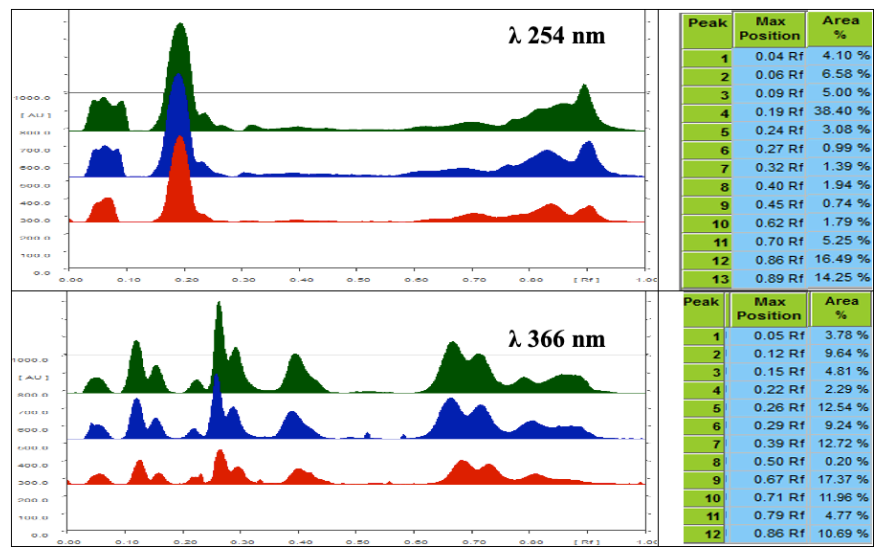


Figure 3. HPTLC finger print profile of chloroform extract of $\mathrm{KL}$

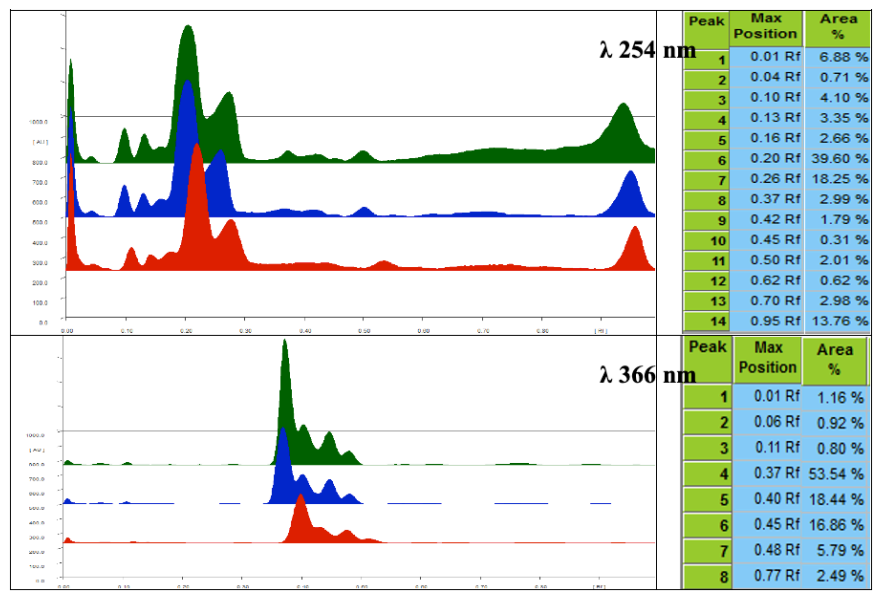

Figure 4. HPTLC finger print profile of ethanol extract of KL

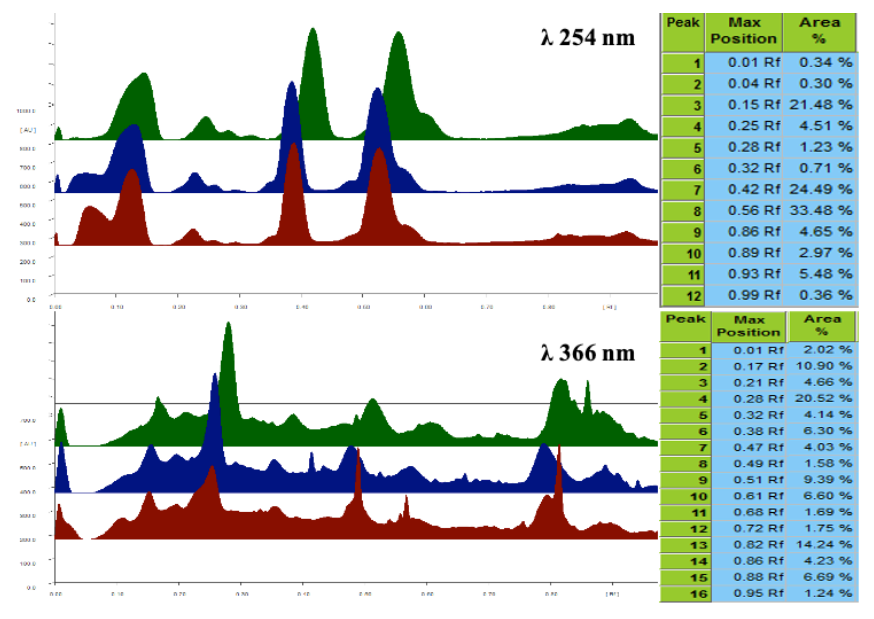

Figure 5. HPTLC finger print profile of hydroalcohol extract of $\mathrm{KL}$

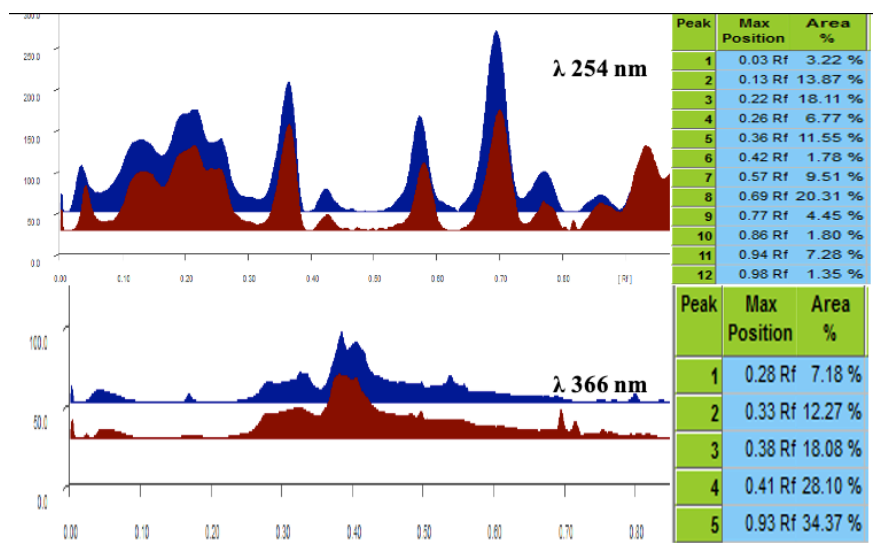

The approach of fingerprint analysis through HPTLC has become the effective technique for quality control of herbal drugs due to its simplicity, flexibility and reliability. It serves as a device for identification, authentication and quality control of herbal drugs. The development of chromatographic finger prints acts as a significant role in the quality control of complex herbal medicines $(14,15)$. Ellagic and gallic acid in Triphala churnam, in which T. chebula is one of the ingredients, were estimated by HPTLC (16).

\section{Conclusion}

Kadukkai Legiyam is a combination of 20 herbs. This study gives information about physicochemical, phytochemical analysis and HPTLC fingerprint profile of different extracts which will be useful in quality assessment of the drug and batch comparison studies.

\section{Acknowledgement}

Authors are thankful to The Director General, CCRS and The Assistant Director I/c, SCRI for facility and encouragement.

\section{Conflict of Interest}

The authors declare no conflict of interest.

\section{Reference}

1. Siddha Formulary of India, Part II, 1st ed (Tamil Version). Department of AYUSH, Ministry of Health and Family Welfare, Government of India, New Delhi, 2011, pp.65-67.

2. Velayudam, Ilavarasan, Arul Amuthan. Physico-chemical evaluation of kadukkai maathirai and its tablet formulation, a Siddha iron preparation used in anemia. International Journal of Pharmacology and Clinical Sciences. 2012; 1(1): 3-8. https://www.ijphs.org/article/ 2012/1/1-0

3. Velayudam, Arul Amuthan, Ilavarasan. Hepatoprotective activity of kadukkai maathirai (a siddha polyherbal formulation) against carbon tetrachloride induced liver damage in rat. Research Journal of Pharmaceutical Sciences. 2012;1(4): 17-21. http://www.isca.in/IJPS/ Archive/v1/i4/3.ISCA-RJPcS-2012-025.pdf

4. Mohanapriya M, Kanakavalli K, Parthibhan P. Acute and Sub-acute toxicity studies of a herbal formulation Kadukkai Chooranam. Journal of Research in Biomedical Sciences 2019; 2(4): 86-95. https://doi.org/10.124583/ jrbms.v2i4.50

5. Priya F, Velpandian V, Ayyasamy S, Pitchiahkumar M. Hypolipidemic activity of Kadukkai Chooranam (Terminalia chebula) in Triton WR-1339 induced hyperlipidemic rats. IOSR Journal of Pharmacy and Biological Sciences (IOSR-JPBS). 2013; 5(5): 77-84. http://www.iosrjournals.org/iosr-jpbs/papers/Vol5-issue5/ N0557784.pdf?id=4880.

6. The Siddha Pharmacopoeia of India, Part 1, Vol. 1, 1st edition, 2008, pp.81-82.

7. Bag A, Bhattacharyya SK, Chattopadhyay RR. The development of Terminalia chebula Retz.(Combretaceae) in clinical research. Asian Pacific Journal of tropical biomedicine. 2013; 3(3): 244-52. DOI: 10.1016/ S2221-1691(13)60059-3

8. Kundu AP, Mahato SB. Triterpenoids and their glycosides from Terminalia chebula. Phytochemistry. 1993; 32(4): 999-1002. https://doi.org/10.1016/0031-9422(93)85243K

9. Nair V, Singh S, Gupta YK. Anti-arthritic and disease modifying activity of Terminalia chebula Retz. in experimental models. Journal of Pharmacy and Pharmacology. 2010; 62(12): 1801-6. DOI: 10.1111/ j.2042-7158.2010.01193.x.

10. Naik GH, Priyadarsini KI, Naik DB, Gangabhagirathi R, Mohan H. Studies on the aqueous extract of Terminalia 


\section{International Journal of Ayurvedic Medicine, Vol 12 (4), 922-926}

chebula as a potent antioxidant and a probable radioprotector. Phytomedicine. 2004; 11(6): 530-8. DOI: 10.1016/j.phymed.2003.08.001

11. Lohar DR. Protocol for testing of Ayurveda, Siddha and Unani medicine. New Delhi, Pharmacopoeial Laboratory for Indian Medicine, Department of AYUSH, Ministry of Health and Family Welfare, Government of India. 2008.

12. Harborne JB. Phytochemical Methods, Chapman and Hall, London. 1973; 278.

13. Marini-Bettolo GB. Chapter 25 - The function of Pharmacopoeia Standards. In: The Quality Control of Medicines. Proceedings of the 35th International Congress of Pharmaceutical Sciences, Dublin, 1975. 1976, p.383-91. https://doi.org/10.1016/ B978-0-444-41454-0.50030-1.
14. Attimarad M, Mueen Ahmed KK, Aldhubaib BE, Harsha S. High-performance thin layer chromatography: a powerful analytical technique in pharmaceutical drug discovery. Pharma Methods. 2011; 2(2): 71-4. https:// doi.org/10.4103/2229-4708.84436

15. Lalhriatpuii T. HPTLC Fingerprint in Herbal Drug Formulations. In: Sen S., Chakraborty R. (eds) Herbal Medicine in India. Springer, Singapore. 2020, p p.337-362. ht ps://doi.org/ 10.1007/978-981-13-7248-3_22.

16. Jeganathan NS, Kannan K. HPTLC method for estimation of ellagic acid and gallic acid in Triphala churnam formulations. Res J Phytochem. 2008; 2(1): 19. https://scialert.net/abstract/?doi=rjphyto.2008.1.9. 